\title{
Assessing Sediment and Nutrient Transport in the Pra Basin of Ghana
}

\author{
S. A. Akrasi* and O. D. Ansa-Asare \\ CSIR-Water Research Institute, P. O. Box M. 32, Accra, Ghana \\ *Corresponding author; Email: samakrasi@yahoo.com
}

\begin{abstract}
Regression analysis was used to establish relationships between suspended sediment yield and nutrient export coefficient as the dependent variable, and runoff and catchment area as the independent variables. The established regression equation can be used to estimate suspended sediment or nutrient yield at any cross-section within the drainage basin with no sediment or nutrient data, if the mean annual runoff and catchment area are known. The equation can also be used to estimate the total suspended sediment and nutrient transport into the sea. The Pra basin of Ghana, which is made up of the Birim, Offin and Pra sub-basins, had $\mathrm{PO}_{4}-\mathrm{P}$ loads from mainly domestic, agricultural and commercial activities. The nutrient loads of Pra basin showed a general trend of increasing downstream. The high load of $14.6 \mathrm{t} \mathrm{day}^{-1}$ at Twifo-Praso is mainly due to palm oil production. Those of Dunkwa $\left(1.98 \mathrm{t} \mathrm{day}^{-1}\right)$ and Beposo $\left(2.74 \mathrm{t} \mathrm{day}^{-1}\right)$ were mainly due to domestic and commercial activities. The suspended sediment and nutrient transport into the sea are estimated by the model to be about $1.2 \times 10^{6}$ tonnes for suspended sediment, 792 tonnes for nitrates nitrogen, 3 kilo tonnes for ortho-phosphrous phosphate, 141 kilo tonnes for sulphate and 188 kilo tonnes for silicate.
\end{abstract}

\section{Introduction}

Information on water resources of a basin is a prerequisite to the orderly development and management of the resources for socio-economic advancement. Among the most important requirements in water resources development, management and conservation are information on sediment and nutrient loads of rivers. Fluvial sediment affects not only the quality of water for domestic and other purposes, but also the operation and integrity of hydraulic structures such as dams, canals and bridges. Therefore, in the design of such structures, knowledge of both the quantity and characteristics of fluvial sediment is essential.

Human activities in watersheds can increase nutrient loads carried into surface waters by runoff and enhance primary production (Sharpley \& Menzel, 1987). Geology, physiography, hydrology, soil texture, and dominant vegetation influence nutrient export from watersheds. In the UK, the enrichment of surface waters with nutrients has been linked to increased growth of freshwater phytoplankton (Heathwaite, 1993). Problems due to eutrophication within the UK have, until now, largely been associated with freshwater systems. In the United States, nutrient export from agricultural lands to the river courses can be up to between 3 and 12 times high in order of magnitude (Omernik, 1977).

The Pra basin, which is part of the south-western river basin system of Ghana, has two major subbasins as tributaries, namely the Birim and the Offin. The Pra, which is an important source of water supply for the people in its catchment area, is being polluted with waste discharges and mining activities. For many people in Ghana, water supply, sanitation and safe disposal of waste remain the most important of all environmental problems. Control and sustainable management of watersheds are major issues in Ghana because of human activities. These include nutrient enrichment of surface waters from urban sources and by agricultural chemicals, soil degradation caused by deforestation, eutrophication, improper land management, abstraction of water for human consumption and irrigation.

The demand for adequate water to satisfy the ever increasing needs through conservation and regulation has necessitated the need to identify the various sources of contaminants carried into rivers by runoff. This then necessitated the assessment of the sediment yield and nutrient loads of the Pra river basin. The method that has been developed was used to estimate the nutrient and suspended sediment transport from the basin into the sea.

Study area

Materials and methods

West African Journal of Applied Ecology - Volume 13 
The Pra basin (Fig. 1), being part of the South-western basin system in Ghana, has a drainage area of $23188 \mathrm{~km}^{2}$ and an estimated mean annual discharge of $214 \mathrm{~m}^{3} \mathrm{~s}^{-1}$. It is quite humid (relative humidity $60-95 \%$ ) with annual rainfall in the range of $1500-2000 \mathrm{~mm}$. The average maximum and minimum temperatures are $32{ }^{\circ} \mathrm{C}$ and $21{ }^{\circ} \mathrm{C}$, respectively, for the cooler periods of JuneSeptember/October. The basin comes strongly under the influence of the moist south-west monsoons during the rainy season. The primary vegetation consists of moist semi-deciduous forest.

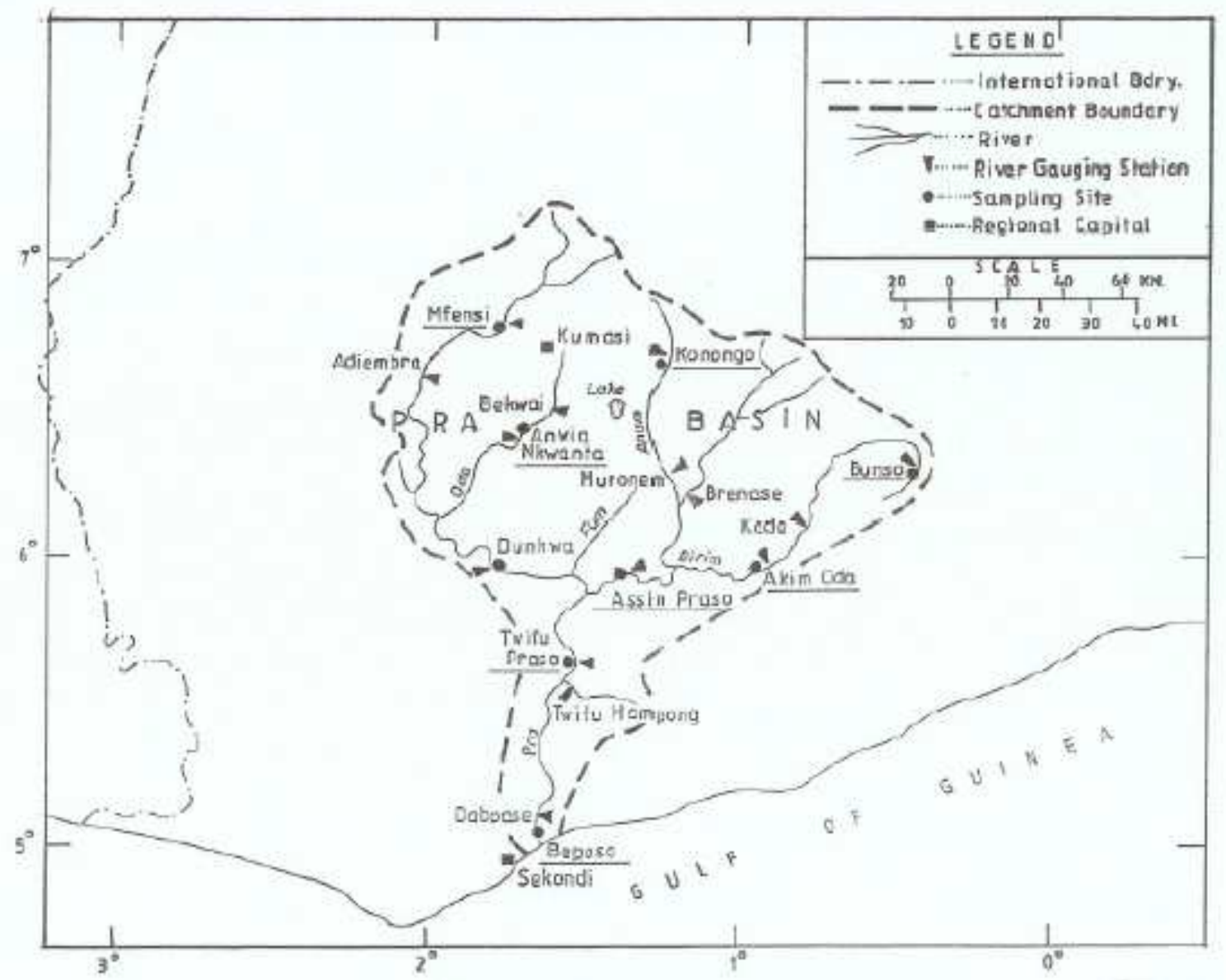

Fig. 1. Map of Pra Basin showing Sompling Sites

The moist semi-deciduous vegetation has forest ochrosols as the main soil type. The soil is alkaline in nature. Furthermore, the underlying rock of the region is pre-Cambrian and is classified into Birrimian and Tarkwaian rocks. These are impervious where groundwater occurs in fractured zones. The Pra has two major tributaries, Birim and the Offin rivers (Dickson \& Benneh, 1980).

The population is made up of mainly farmers, who grow foodstuffs, oil palm, vegetables, fruits and cash crops such as cocoa and coffee. Cutting of trees for fuelwood and charcoal production for domestic uses, excessive use of inorganic fertilizer in agricultural activities, land degradation as a result of poor farming practices, and timber extraction from the forest are some of the human induced activities that cause pollution of the river bodies in the basin. The activities of small-scale miners have also degraded the land and littering parts of the basin with trenches and water-filled excavations that has not been 
reclaimed. These generally have turbid waters containing other pollutants from gold extraction and diamond mining.

A programme of water and suspended sediment sampling was undertaken for all the nine stations shown in Fig. 1. Starting at Beposo on the Pra river in January 1987, it was extended to Assin-Praso, Twifo-Praso, Oda and Dunkwa in January 1989. Konongo, Bunso, Mfensi and Anwia-Nkwanta were added in January 1991. The flow data used was collected from 1971 to 1996 . The suspended sediment samples were taken near the bank with sample bottles. The gauge readers of the Hydrological Services of the Ministry of Water Resources, Works and Housing were contracted to collect the suspended sediment samples. Samples were collected as frequently as possible depending on the stage of the river. The water level at the time of sampling was read from the staff gauge.

The water samples were collected in clean 500-ml plastic bottles for nutrient analysis in the laboratory. All nutrients were analysed within $0.1-09 \%$ relative standard deviation, using colorimetric methods (APHA, 1975). The nutrient and sediment data gathered covered a period from 1980 to early 1990. The samples collected in the field were analyzed in the CSIR-Water Research Institute's laboratories for suspended sediment and nutrient concen-trations.

\section{Nutrient and sediment loads computation}

The results of the concentration analyses were used to compute the suspended sediment, and nutrient discharges of the rivers at the stations named. The formula used is outlined by Tilrem (1979), and is of the form:

$$
Q_{s, n=} K C_{s} Q_{w}
$$

where $Q_{s, n}=$ suspended sediment or nutrient discharge $\left(\mathrm{t} \mathrm{day}^{-1}\right), K=0.0864, C_{s}=$ suspended sediment or nutrient concentration $\left(\mathrm{mg} \mathrm{l}^{-1}\right)$ and $Q_{w}=$ water discharge $\left(\mathrm{m}^{3} \mathrm{~s}^{-1}\right)$. Regression analysis was used to establish simple relationships between suspended sediment yield and nutrient export coefficient (computed by dividing the total nutrient load by catchment area) as the dependent variable, and runoff and catchment area as the independent variables. The established relationship was used to estimate the total suspended sediment and nutrient discharges into the sea.

The data set used in the study for the regression analysis consisted of mean annual runoff, catchment area and suspended sediment yield or nutrient export coefficient (Akrasi \& Amisigo, 1993; Larmie et al., 1996). The original suspended sediment data was collected without the use of depth-integrating suspended sediment sampler. Instead, dipping of ordinary sample bottle was used to collect the samples near the bank. This method of sampling is likely to underestimate the suspended sediment concentration in the overall cross-section. In the absence of specialized samplers (depth-integra-ting, etc.) to correct the under-estimation of the concentration values, reference was made to studies that have used similar methods for correction factors.

A study carried out in South Africa and reported by Rooseboom \& Annandale (1981) compared suspended sediment concentration of ordinary sampling bottles and sophisticated methods (Turbisonade). In the study, the concentra-tions of the surface samples were $25 \%$ less than the concentrations of the vertical samples. A similar study, conducted at the Sidi Bei Alter gauging station on the Oued Chieft in Algeria, compared instantaneous load calculated using near-bank surface samples with detailed sampling using Neyrpic Turbisonade method. The study also concluded that the instantaneous load underestimated the load by about 25\% (Demmak, 1976). In the absence of depth-integrating sampling data a correction factor of $25 \%$ was used and the measured concentration values were increased by $25 \%$.

The suspended sediment and nutrient discharges using Equation 1 were applied to the corresponding water discharges to establish suspended sediment and nutrient rating curves, using least square fit on logtransformed values of sediment nutrient and water discharges. The rating equation obtained was of the form (Table 1):

TABLE 1

West African Journal of Applied Ecology - Volume 13 
Parameters for Equation 2

$\begin{array}{lllll}\text { Station } & \text { Rive } & k & n & r^{2} \\ & & & & \\ \text { Mfensi } & \text { Ofin } & 1.363 & 1.328 & 0.81 \\ \text { Anwia-Nkwanta } & \text { Ofin } & 5.514 & 1.135 & 0.86 \\ \text { Bunso } & \text { Birim } & 1.423 & 1.305 & 0.84 \\ \text { Oda } & \text { Birim } & 4.086 & 1.105 & 0.90 \\ \text { Konongo } & \text { Anum } & 3.132 & 1.128 & 0.91 \\ \text { Assin-Praso } & \text { Pra } & 1.083 & 1.331 & 0.90 \\ \text { Twifu-Praso } & \text { Pra } & 4.473 & 1.137 & 0.86 \\ \text { Beposo } & \text { Pra } & 5.753 & 1.099 & 0.87\end{array}$

$$
Q_{s}=k O_{w}{ }^{n}
$$

where $Q_{s=}$ suspended sediment or nutrient discharge $\left(\mathrm{t} \mathrm{day}^{-1}\right), Q_{w}=$ water discharge in $\mathrm{m}^{3} \mathrm{~s}^{-1}, k=$ constant and $\mathrm{n}=$ exponent.

The bias correction factor proposed by Ferguson (1986) was applied to correct the bias associated with log-transformed values. This then corrected the underestimation of sediment and nutrient loads. The rating curves were applied to long-term flow-duration curves available for the measuring stations to estimate the mean annual suspended sediment yields and nutrient loads for these stations (Miller, 1951; Walling, 1977).

In view of the small number of sediment yield and nutrient export coefficient values available to establish the model, it was important to keep the number of independent variables as small as possible, in order to increase the statistical significance of the resulting regression equation. Both the dependent and independent variables were log-transformed, and the resulting prediction equation takes the form:

$$
S_{y}, Q_{n}=K U_{1}^{a} U_{2}^{b} \ldots \ldots . . U_{n}^{z}
$$

where $S_{y}, Q_{n}=$ the mean annual specific suspended sediment yield or nutrient load(t km-2 year ${ }^{-1}$ or t year $\left.{ }^{1}\right), \mathrm{K}=$ the regression constant and $U_{1}, U_{2} \ldots \ldots U_{n}=$ the independent variables.

To measure the agreement between the model and the observed data, and also to estimate the degree of correlation between the dependent and independent variables, the coefficient of determination $R^{2}$ was used. Because of the limited size of the data, $R^{2}$ (adjusted $R^{2}$ ) was used. The significance of $R^{2}$ was verified by determining the statistic:

$$
F=(n-k) R^{2} /(k-1)\left(1-R^{2}\right)
$$

which, in this case, is from Fisher's distribution (Velinova \& Koumanova, 1995). The computed value of $F\left(F_{\text {comp }}\right)$ was compared with $F$ from tables $\left(F_{t a b}\right)$ for $\pm=0.05,1 / 2_{1}=\mathrm{k}-1,1 / 2_{2}=\mathrm{n}-\mathrm{k}$ under the condition (Draper \& Smith, 1981):

$$
F_{\text {comp }} \geq 4 F_{\text {tab }}
$$

The significance of the regression coefficients were tested using the F-test (Yamane, 1970).

The adequacy of the models were investigated by comparing the variance of the output data set $\left(S_{y}^{2}\right)$ and the residual variance $\left(S_{r e s}^{2}\right)$ :

$\mathrm{S}_{\mathrm{res}}^{2}=\Sigma \mathrm{d}_{\mathrm{i}}^{2} /(\mathrm{n}-\mathrm{k})=\Sigma\left(\mathrm{Y}_{\mathrm{i}}-\mathrm{v}\right)^{2} /(\mathrm{n}-\mathrm{k}) \quad(6)$

where $d_{i}=\left(Y_{i}-v\right)$ is the ith residual; $Y_{i}$ is the ith measured value of the output function and $v_{i}$ is the ith computed value of the output function. In this case the statistic $F^{\prime}=S_{y}^{2} / S_{r e s}^{2}$ indicates how many times the deviation around the regression equation decreases, regarding the deviation around the mean of the data set. The values of $F_{\text {comp }}^{\prime}$ were compared with $F_{\text {tab }}^{\prime}$ for $\pm=0.05,1 / 2_{1}=\mathrm{n}-1$ and $1 / 2_{2}=\mathrm{n}-\mathrm{k}$.

The examination for systematic error in the models was carried out by trying to reject the null hypothesis that the residual mean $(\delta)$ belongs to a general population with a mean of zero (the sets of values of measured and computed values of the output function are believed to have the same variances).

West African Journal of Applied Ecology - Volume 13 
Then the Student's statistic is:

$$
t=\delta \sqrt{ } n / S_{d}
$$

where is the residual mean, $S_{d}$ is the residual standard deviation.

\section{Results and discussion}

Suspended sediment yield

Table 1 gives the summary of rating relationships developed from the suspended sediment concentration data. Each relation-ship was statistically tested to be significant at the 5\% level. The coefficients of determination $\left(\mathrm{r}^{2}\right)$ associated with the relationships ranges between 0.81 and 0.91 .

The multiple regression analysis of the data set gave the relation:

where $Q=$ mean annual runoff $(\mathrm{mm})$ and $A=$ catchment area $\left(\mathrm{km}^{2}\right)$

$$
S_{y}=135.62 Q_{w}^{0.38} A^{-0.17}(8)
$$

The corrected coefficient of multiple determination, $\mathrm{R}^{2}$ obtained from the analysis was 0.85 . This is an indication that the variables, runoff and catchment area accounted for a large proportion of the variance of the suspended sediment yield. The coefficients 0.38 and -0.17 were statistically tested to be significant at 5\% significance level. The established Equation 8 can be used to predict specific suspended sediment yield at any cross-section within the drainage basin with no sediment data, knowing the mean annual runoff and the catchment area. It can also be used to calculate the total suspended sediment discharge of the river into the sea. The positive exponent associated with mean annual runoff indicates that specific suspended sediment yield increases in areas with a higher mean annual runoff, and this in turn reflects the increased erosion and suspended sediment transport associated with increased runoff.

The relationship between specific suspended sediment yield and catchment area has been viewed to be negative (Walling \& Webb, 1996). The negative relationship is commonly explained in terms of the increasing opportunity for sediment deposition and storage, both on the slopes of a catchment and within the channel system, as catchment area and travel distances and travel times increase. It also suggests that slope or upland erosion is dominant over channel erosion in the Pra basin system. The mean runoff is a measure of the sediment transport capability of the runoff and these results indicate that transport capacity is a very important factor influencing specific suspended sediment yield in the basin.

Table 2 shows the average annual suspended sediment yield of the drainage areas controlled by the stations. The suspended sediment yields in the drainage basin are low to average compared to that of other drainage basins in the tropics. The mean suspended sediment yield of the whole Pra drainage basin was estimated by equation (8) to be $50.8 \mathrm{t} \mathrm{km}^{-2}$ year $^{-1}$. The yield is higher than that obtained for the Black Volta $\left(28.1 \mathrm{t} \mathrm{km}^{-2}\right.$ year-1) and White Volta $\left(32.6 \mathrm{t} \mathrm{km}^{-2} \mathrm{year}^{-1}\right)$, and lower than that for Oti $\left(63.3 \mathrm{t} \mathrm{km}^{-2}\right.$ year $\left.{ }^{1}\right)$ in Ghana (Akrasi, 2005). The suspended sediment yield is higher than the suspended sediment yields for Niger $\left(4.5 \mathrm{t} \mathrm{km}^{-2}\right.$ year $\left.{ }^{-1}\right)$, Congo $\left(16.2 \mathrm{t} \mathrm{km}^{-2} \mathrm{year}^{-1}\right)$ and Nile $\left(37.3 \mathrm{t} \mathrm{km}^{-2}\right.$ year $\left.^{-1}\right)$. The yield is, however; lower than the yields for Amazon $\left(62.8 \mathrm{t} \mathrm{km}^{-2}\right.$ year $\left.^{-1}\right)$ and Ganges $\left(1352 \mathrm{t} \mathrm{km}^{-2}\right.$ year $\left.^{-1}\right)$ (Stocking, 1984).

TABLE 2

Annual average values of suspended sediment yield in the Pra river basin

$\begin{array}{llrrrl}\text { Station } & \text { River } & A\left(\mathrm{~km}^{2}\right) & Q\left(\mathrm{~m}^{3} \mathrm{~s}^{-1}\right) & S_{y}\left(\mathrm{~km}^{2} \text { year } \mathrm{r}^{-1}\right) & \text { Local activity } \\ \text { Mfensi } & \text { Ofin } & 1515 & 10.3 & 24.76 & \text { Farming } \\ \text { Dunkwa } & \text { Ofin } & 8345 & 76.2 & 45.12 & \text { Dredging } \\ \text { Anwia-Nkwanta } & \text { Oda } & 1303 & 8.5 & 26.91 & \text { Farming } \\ \text { Bunso } & \text { Birim } & 150 & 3.7 & 24.32 & \text { Farming } \\ \text { Oda } & \text { Birim } & 3248 & 43.4 & 39.95 & \text { Mining } \\ \text { Konongo } & \text { Anum } & 681 & 4.3 & 17.90 & \text { Farming } \\ \text { Assin-Praso } & \text { Pra } & 9793 & 88.1 & 32.60 & \text { Farming } \\ \text { Twifu-Praso } & \text { Pra } & 20767 & 153.0 & 44.11 & \text { Farming }\end{array}$

West African Journal of Applied Ecology - Volume 13 
$\left(\mathrm{Q}=\right.$ water discharge, $\mathrm{A}=$ drainage basin area, $\mathrm{S}_{\mathrm{y}}=$ suspended sediment yield .

The predicted suspended sediment yield was plotted against the observed suspended sediment yield (Fig. 2). The entire observed specific suspended sediment yields are closely matched by the predicted values obtained by Equation 8. This confirms that Equation 8 can be used to predict specific suspended sediment yield of any river basin within the Pra basin. The reliability of Equation 8 is similar to one developed by Hydraulics Research Limited for eastern and southern Africa (Lawrence, 2003) and Water Research Institute (Akrasi, 2005).

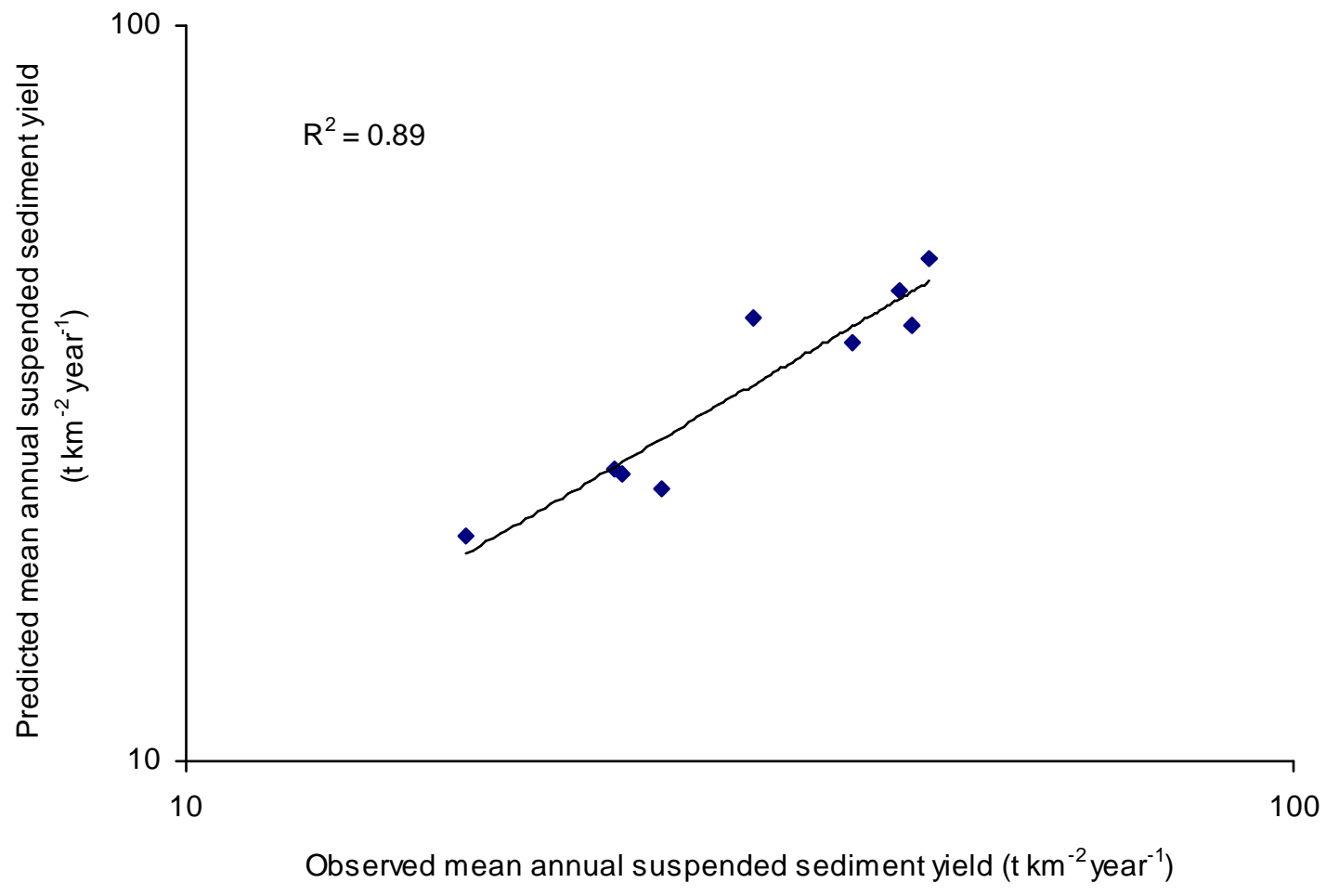

Fig 2: The plot of predicted and observed mean annual suspended sediment yields of selected stations in the Pra basin

Table 4 gives the parameters needed to determine the efficiency and adequacy verifications of the model, as well as the testing of the systematic error in the model. From Table $4, \mathrm{~F}_{\text {comp }}$ is greater than $4 \mathrm{~F}_{\text {tab }}$ and $\mathrm{F}_{\text {comp }}$ is greater than $\mathrm{F}_{\text {tab }}$. It can, therefore, be assumed that for the suspended sediment yield model (Equation 8), the coefficient of determination $\mathrm{R}^{2}$ is significant and the model adequacy could not be rejected. Again, no constant system error could be observed in the model for the $95 \%$ significance level since from Table $4, \mathrm{t}_{\text {comp }}$ is less than $\mathrm{t}_{\text {tab }}$. The analysis shows that the parameters for the model formulation 
have a significant influence on the output function. All possible corrections were introduced because of the limited size of the data set. Equation 8 was applied to the whole basin and the sediment yield of the Pra basin is estimated to be $50.8 \mathrm{t} \mathrm{km}^{2}$ year ${ }^{-1}$, which amounts to about $1.2 \times 10^{6}$ tonnes of suspended sediment into the sea.

TABLE 3

Pra basin nutrient load

$\begin{array}{lcccrr}\text { Stations } & Q_{w}\left(m^{3} s^{-1}\right) & \mathrm{NO}_{3}-\mathrm{N}\left(\text { tday }^{-1}\right) & \mathrm{PO}_{4}^{-P}\left(\text { tday }^{-1}\right) & \mathrm{SO}_{4}\left(\text { tday }^{-1}\right) & \mathrm{SiO}_{2}\left(\text { t day }^{-1}\right) \\ \text { Mfensi } & & & & & \\ \text { Dunkwa } & 10.3 & 0.36 & 0.23 & 5.72 & 19.76 \\ \text { Anwia-Nkwanta } & 76.2 & 0.93 & 1.98 & 138.26 & 168.54 \\ \text { Bunso } & 8.5 & 0.29 & 0.53 & 5.12 & 18.29 \\ \text { Oda } & 3.7 & 0.10 & 0.01 & 1.10 & 4.16 \\ \text { Konongo } & 43.4 & 1.28 & 0.75 & 67.50 & 86.24 \\ \text { Assin-Praso } & 4.30 & 0.07 & 0.07 & 5.16 & 8.81 \\ \text { Twifu-Praso } & 88.1 & 0.76 & 1.52 & 57.39 & 135.49 \\ \text { Beposo } & 153 & 1.32 & 11.83 & 276.75 & 526.44 \\ & 211 & 1.82 & 4.38 & 311.00 & 428.62\end{array}$

TABLE 4

Results of efficiency and adequacy verifications and testing of systemic error in models

$\begin{array}{llrrrrrr}\text { Model } & R^{2} & F_{\text {comp }} & 4 F_{\text {tab }} & F_{\text {comp }}^{\prime} & F_{\text {tab }}^{\prime} & t_{\text {comp }} & t_{\text {tab }} \\ 5 & & & & & & & \\ 6 & 0.85 & 46.85 & 22.36 & 6.58 & 3.73 & 0.12 & 1.86 \\ 7 & 0.84 & 36.75 & 22.36 & 4.69 & 3.73 & 0.06 & 1.86 \\ 8 & 0.96 & 133.00 & 22.36 & 3.83 & 3.73 & 0.25 & 1.86 \\ 9 & 0.94 & 110.00 & 22.36 & 13.95 & 3.73 & 0.26 & 1.86 \\ & 0.98 & 343.00 & 22.36 & 9.23 & 3.73 & 0.28 & 1.86\end{array}$

\section{Regression model of nutrient loads}

The relationship between rainfall and nutrient concentration in water courses is complicated by uncertainty of the residence time of the rain water in the soil profile. Rain water reaches the river water rapidly by surface runoff or slowly as it leaches through the soil profile. Runoff from storm events delivers greater nutrient loads from cropland and forested watersheds than any other event. In this study, regression analysis was used to establish a relationship between the nutrient export coefficient as dependent variable and runoff and catchment area, as the independent variables. The regression equations obtained by the individual nutrients and the various independent variables are as follows:

$$
\begin{aligned}
& Q_{\text {NO3-N }}=0.005 Q^{0.847} A^{0.71} \\
& Q_{\text {PO4-P }}=0.95 Q^{-0.837} A^{1.259} \\
& Q_{\text {SO4 }}=0.004 Q^{0.828} A^{1.260} \\
& Q_{\text {SiO2 }}=0.088 Q^{0.654} A^{1.077}
\end{aligned}
$$

where $Q_{N O 3-N}=$ mean annual nitrate nitrogen load (tonnes), $Q_{P O 4-P}=$ mean annual ortho-phosphorus phosphate load (tonnes), $Q_{S O 4}=$ mean annual sulphate load (tonnes), $Q_{S i O 2}=$ mean annual silicate load (tonnes), $Q=$ mean annual runoff $(\mathrm{mm})$ and $A=$ catchment area $\left(\mathrm{km}^{2}\right)$

The corrected coefficient of multiple determinations $\mathrm{R}^{2}$ obtained from the analysis ranged between 0.84 and 0.98 (Table 4). This is an indication that the variables, runoff and catchment area accounted for a large proportion of the variance of the nutrient loads. From Table $4, \mathrm{~F}_{\text {comp }}$ is greater than $4 \mathrm{~F}_{\text {tab }}$ and $\mathrm{F}_{\text {comp }}$ is 
greater than $\mathrm{F}_{\text {tab. }}$. The exponents were statistically significant at the $5 \%$ level. It can, therefore, be assumed that for the nutrient load models (Equations 9-12), the coefficients of determination $\mathrm{R}^{2}$ are significant and the models adequacy could not be rejected. Again, no constant system error could be observed in the models for the $95 \%$ significance level since in all the models $t_{\text {comp }}$ is less than $t_{\text {tab }}$ (Table 4$)$. The analysis shows that the parameters for the models formulation have significant influence on the output functions. All possible corrections were introduced because of the limited size of the data sets.

The predicted nitrate nitrogen, ortho-phosphorus phosphate, sulphate and silicate export coefficients were plotted against the observed nutrients export coefficients, ortho-phosphorus phosphate, sulphate and silicate loads (Fig. 3). All the observed export coefficients are closely matched by the predicted values obtained by Equations 9-12. This confirms that Equations 9-12 can be used to predict nitrate nitrogen, ortho-phosphorus phosphate, sulphate and silicate loads of any river basin within the Pra basin.

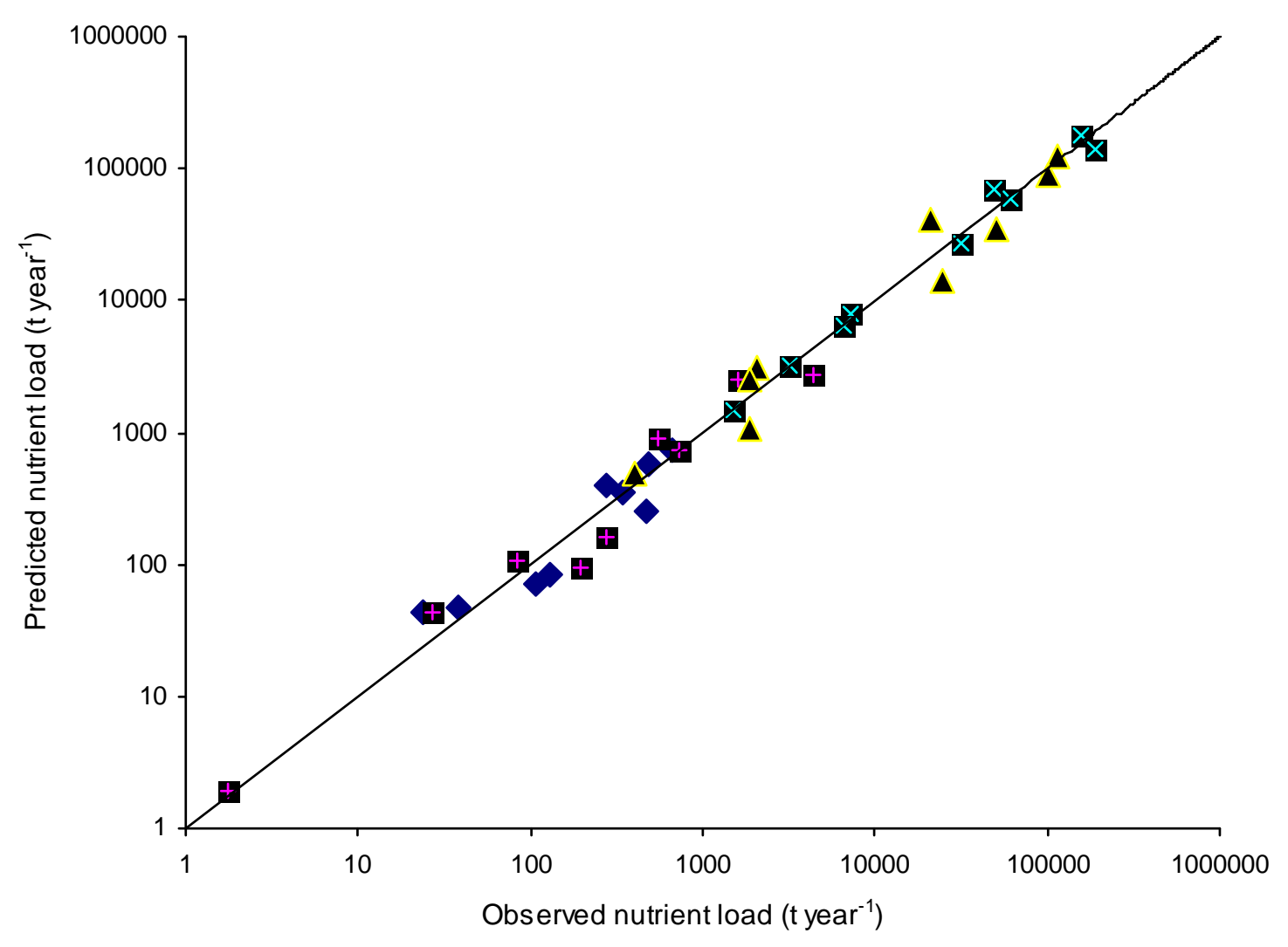

Fig 3: Plots of predicted nutrient loads vrs observed loads

$\bullet$ NO3-N \#PO4-P $\triangle \mathrm{SO}$ 凶SiO2

\section{Nutrient loads in Pra basin}

Nitrate $\left(\mathrm{NO}_{3}-\mathrm{N}\right)$. From Table 2 the Pra river basin has a general trend of nutrient load increasing from upstream to downstream. The mean nitrate load for Pra basin is estimated to be $2.17 \mathrm{t}^{-1} \mathrm{y}^{-1}$, reflecting the West African Journal of Applied Ecology - Volume 13 
impact of agricultural activities in the basin. The nitrate loads at Oda $\left(2.10 \mathrm{tday}^{1}\right)$, Twifo-Praso $\left(1.33 \mathrm{t}\right.$ day $\left.^{-1}\right)$ and Beposo $\left(1.82 \mathrm{t} \mathrm{day}^{-1}\right)$ were extremely high as a result of domestic and agricultural activities in that part of the basin.

Linear relationships were established between discharge and $\mathrm{NO}_{3}-\mathrm{N}$ concentra-tion. $\mathrm{NO}_{3}-\mathrm{N}$ concentration tended to be highest in periods of high discharge and lowest in periods of low discharge, although the variation in discharge was much greater than the variation in $\mathrm{NO}_{3}-\mathrm{N}$ concentrations, indicative of a diffuse source. The mean annual $\mathrm{NO}_{3}-\mathrm{N}$ loss from the basin was $792 \mathrm{t}^{\mathrm{year}}{ }^{-1}$. The Pra basin also had an annual $\mathrm{NO}_{3}-\mathrm{N}$ yield of about $34 \mathrm{~kg} \mathrm{~km}^{-2}$ year'-1 (Table 2.) The nitrate-nitrogen transport into the sea is estimated by the model to be 792 tonnes. As regards the export rates of $\mathrm{NO}_{3}-\mathrm{N}$ they vary from less than $10 \mathrm{~kg} \mathrm{~km}^{-2} \mathrm{yr}^{-1}$ in the sub-arctic environment where both $\mathrm{NO}_{3}-\mathrm{N}$ level and water runoff are low to more than $200 \mathrm{~kg} \mathrm{~km}^{-2}$ year-1 $^{-1}$ in the wet tropics (Sumatra and Borneo rivers, Magdalena river in Columbia, Purari river in Papua New Guinea) (Meybeck, 1982).

Ortho-phosphorus $\left(\mathrm{PO}_{4}-\mathrm{P}\right)$. Ortho-phosphorus also had a general trend of increasing load from upstream to downstream. The Pra basin, which is made up of the Birim, Offin and Pra sub-basins, had $\mathrm{PO}_{4}-\mathrm{P}$ loads from mainly domestic, agricultural and commercial activities. The high load of $11.6 \mathrm{tday}^{-1}$ at Twifo-Praso is mainly due to palm-oil production. The $\mathrm{PO}_{4}-\mathrm{P}$ load of Dunkwa $\left(1.98 \mathrm{t}^{\mathrm{day}}{ }^{-1}\right)$ and Beposo (4.38 $\mathrm{t} \mathrm{day}^{-1}$ ) were mainly due to domestic and commercial activities. Mean $\mathrm{NO}_{3}-\mathrm{N}$ and $\mathrm{PO}_{4}-\mathrm{P}$ loads varied considerably from station to station (Table 3) closely reflecting the influence of the rains. The mean yearly loss of 3 kilo tonnes year ${ }^{-1}$ of $\mathrm{PO}_{4}-\mathrm{P}$ means that the annual loss in terms of yield from the basin is $110 \mathrm{~kg} \mathrm{~km}^{-2}$ year. The variations in discharge were considerably different from station to station and, consequently, mean daily loads were also highly variable.

$\mathrm{PO}_{4}-\mathrm{P}$ load exported from agricultural and forested catchments was three times more than that of $\mathrm{NO}_{3}-$ $\mathrm{N}$ load. However, $\mathrm{NO}_{3}-\mathrm{N}$ is known to be more soluble and can be exported more frequently through runoffs than $\mathrm{PO}_{4}-\mathrm{P}$. The predominance of $\mathrm{PO}_{4}-\mathrm{P}$ in runoff from watersheds in the Pra basin may be due to watershed characteristics such as gentle slopes, which result in longer leaching times and a high proportion of organic soils. This is because $\mathrm{PO}_{4}-\mathrm{P}$ predominates in run-off from Pra basin, typical erosion control measures such as grassed filter strips may not be sufficient to reduce dissolved $\mathrm{P}$ inputs to aquatic stems (Sharpley et al., 1981).

Sulphate $\left(\mathrm{SO}_{4}\right)$. The mean daily sulphate load in Pra basin is estimated to be $385 \mathrm{t} \mathrm{day}^{-1}$, a reflection of domestic and mining activities. The high levels of sulphate recorded at Twifo-Praso (277 t day $\left.^{-1}\right)$ and Beposo $\left(311 \mathrm{t} \mathrm{day}^{-1}\right)$ were as a result of the impact of palm oil production and mining activities on the river waters downstream. The mean daily loss of sulphate in the basin of $385 \mathrm{t}^{-1 a y^{-1}}$ equates mean annual losses in terms of yield from the basin to be $6.07 \mathrm{t} \mathrm{km}^{-2}$ year $^{-1}$. The sulphate values varied considerably from station to station with discharge, reflecting the influence of the rains. The sulphate load of $138 \mathrm{t} \mathrm{day}^{-1}$ at Dunkwa was also due to the dredging activities being carried out in that area.

Silicate $\left(\mathrm{SiO}_{2}\right)$. Silicate load varied from station to station with discharge. Even though the water discharge at Twifo-Praso was lower than that of Beposo (Table 3), the silicate load of Twifo-Praso was higher than that of Beposo. This is a reflection of the activities impacting on the sediments. It is believed that there might be more silica-demanding organisms in this portion of the river course. This is because the exoskeletons of the organisms descend from the upper layer to re-dissolve below or deposited on the sediment where they are re-dissolved later. Humic compounds and the formation of iron and aluminiumsilicate-humic complexes also increase solubility of silica. The mean daily silicate load in the Pra basin is $515 \mathrm{t} \mathrm{day}^{-1}$, indicating domestic and mining activities. The silicate yield of the basin is estimated to be $8.11 \mathrm{t} \mathrm{km}^{2}$ year ${ }^{-1}$.

\section{Conclusion}

West African Journal of Applied Ecology - Volume 13 
Suspended sediment and nutrient data collected within the Pra basin have been analysed, and the yield and loads obtained have been used to develop simple empirical models predicting specific suspended sediment yield and nutrient export coefficients within the Pra basin. All the statistics on the models showed that the models are reliable and the parameters used for the formulation of the models have significant influence on the output functions.

The sediment yields in the Pra basin $\left(50.2 \mathrm{t} \mathrm{km}^{-2} \mathrm{year}^{-1}\right)$ may be considered to be low to moderate. They are, however, within the range of 3.9-85.0 t km-2 year-1 obtained for some major rivers in various parts of West Africa (Walling, 1984). Forest reserves, secondary forest, cocoa, coffee and oil palm plantations cover the Pra river drainage area. These types of vegetation protect the soil from the erosive activity of rainfall that is very high in the basin. However, the analysis showed that sediment yield is high due to activities mentioned above. The increase in sediment yield might be from feeder roads, which has very high density in the drainage area. Activities like over exploitation of timber trees by timber firms, illegal chain saw operators, illegal gold and diamond winning, slash and burn by farmers are also major causes of increased soil degradation.

The Pra basin, which is made up of the Birim, Offin and Pra sub-basins, had $\mathrm{PO}_{4}-\mathrm{P}$ loads from mainly domestic, agricultural and commercial activities. The high load of $11.83 \mathrm{t} \mathrm{day}^{-1}$ at Twifo-Praso is mainly due to palm oil production. Those of Dunkwa (1.98 $\left.\mathrm{t} \mathrm{day}^{-1}\right)$ and Beposo (4.38 $\left.\mathrm{t}^{\mathrm{ay}} \mathrm{y}^{-1}\right)$ were mainly due to domestic and commercial activities. Mean $\mathrm{NO}_{3}-\mathrm{N}$ and $\mathrm{PO}_{4}-\mathrm{P}$ loads varied considerably from station to station (Table 2) reflecting the influence of the rains. The mean yearly loss of 792 tonnes of $\mathrm{NO}_{3}-\mathrm{N}, 3$ kilo tonnes of $\mathrm{PO}_{4}-\mathrm{P}, 141$ kilo tonnes of $\mathrm{SO}_{4}$ and 188 kilo tonnes of $\mathrm{S}_{\mathrm{i}} \mathrm{O}_{2}$ equates to mean annual loss in terms of yield from the basin of about $34,110 \mathrm{t} \mathrm{km}^{-2}$ year $^{-1}$ and 6.1 and $8.1 \mathrm{t} \mathrm{km}^{-2}$ year-1, respectively. The contribution of the catchment area in phosphorus is quite significant; sediment transport plays an important role in phosphorus export.

\section{Acknowledgment}

The authors wish to thank the technical staff of the Surface Water and Environmental Chemistry divisions of the CSIR-Water Research Institute, Accra, for their cooperation and assistance in assembling the data used in the paper.

\section{References}

Akrasi S. A. (2005). The assessment of suspended sediment inputs to Volta Lake. Lakes \& Reservoirs: Research and Management 10: 179-186.

Akrasi S. A. and Amisigo, B. A. (1993). Sediment loads of some major rivers in Ghana. Water Resources Research Institute, Technical Report. Accra.

APHA (1975). WPCF. Standard Methods for the Examination of Water and Wastewater, 14th edn. Washington DC. pp. 273978.

Cooke S. E. and Prepas E. E. (1998). Stream phosphorus and nitrogen export from agricultural and forested watersheds on the Boreal Plain. Can. J. Fish. Aquat. Sci. 55: 2292-2299.

Demmak A. (1976). Note sur l'utilization de la "Turbisonade Neyrpic" pour l'élaboration d'un jaugeage de debit solide. Note Technique, No. 114/ SHYL, DEMRH, Algiers.

Dickson K. B. and Benneh G. (1980). A New Geography of Ghana. Longman Group Limited, London.

Draper N. R. and Smith H. (1981). Applied Regression Analysis. Wiley, New York.

Ferguson R. I. (1986). River loads underestimated by rating curves. Wat. Resour. Res. 22: 74-76.

Heathwaite A. L. (1993). Nitrogen cycling in surface waters and lakes. In Nitrate, Processes, Patterns and Management (T. P. Burt, A. L. Heathwaite and S. T.Trudgill, ed.), pp. 99-140.

Larmie S., Barnes E. A. and Paintsil A. (1996). Development and implementation of surface water quality networks in Ghana. Water Resources Research Institute Technical Report, Accra.

Lawrence P. (2003). Predicting sedimentation rates in African small dams. Newslett. Wat. 16: 9.

Meybeck M. (1982). Carbon, Nitrogen and Phosphorus Transport by World Rivers. Am. J. Sci. 282: 401-450.

Miller C. R. (1951). Analysis of flow duration sediment rating curve method of computing sediment yield. U S Bureau of Reclamation, Denver, Colorado, USA.

West African Journal of Applied Ecology - Volume 13 
Omernik J. M. (1977). Nonpoint sources - stream nutrient level relationships: a nationwide study. PA-600/3-77-105. U.S. Environmental Protection Agency, Corvallis, Oreg.

Rooseboom A and Annandale G. W. (1981). Techniques applied in determining sediment loads in South African rivers. In Erosion and Sediment Transport Measurement (Proc. Florence Symp. June 1981). 219-224. IAHS Publ. No. 133.

Sharpley A. N., Menzel R. G., Smith S. J., Rhodes E. D. and Olness A. E. (1981). The sorption of soluble phosphorus by soil material during transport in runoff from cropped and grassed watersheds. J. envir. Quality. 10: 211-215.

Sharpley A. N and Menzel R. G. (1987). The impact of soil and fertilizer phosphorus on the environment. Adv. Agron. 41: 297324.

Stocking M. (1984). Rates of erosion and sediment yield in the African environment In Challenges in African Hydrology and Water Resources (Proc. Harare Symp., July 1984), pp. 265-283. IAHS Publ. No.144.

Tilrem Q. A. (1979). Sediment transport in streams, sampling, analysis and computation, vol. 5. Manual on Procedures in Operational Hydrology.

Velinova R. R. and Koumanova B. K. (1995). Statistical modelling of wastewater quality: The case of micro-electronics industry. Wat. Res. 29: 2541-2547.

Walling D. E. (1977). Assessing the accuracy of suspended sediment rating curves for a small basin. Wat. Resour. Res. 13: 531538.

Walling D. E. (1984). The sediment yields of African rivers. In Challenges in African Hydrology and Water Resources (Proc. Harare Symp. July 1984). pp. 265-283. IAHS Publ. No.144.

Walling D. E. and Webb B. W. (1988). Reliability of rating curve estimates of suspended sediment yield: some further comments. In Sediment Budgets (Proc. Porto Alegre Symp., Dec. 1988). pp. 337-350. IAHS Publ. No. 174.

Walling D. E. and Webb B. W. (1996). Erosion and sediment yield: Global overviews. In Erosion and Sediment Yield: Global and Regional Perspectives (D. E. Walling and B. W. Webb, ed.), pp. 3-19. IAHS Press, Wallingford, United Kingdom.

Yamane T. (1970) Statistics: An Introductory Analysis. International edn. Harper \& Row, New York. 